\section{Leaf Gas Exchanges and Mineral Ion Composition in Xylem Sap of Iranian Melon Affected by Rootstocks and Training Methods}

\author{
Reza Salehi ${ }^{1}$ and Abdolkarim Kashi \\ Department of Horticultural Sciences, College of Agricultural Science and \\ Engineering, Campus of Agriculture and Natural Resources, University of \\ Tehran, Karaj, 31587-77871, Iran
}

Jung-Myung Lee

Department of Horticulture, Kyung Hee University, Yongin 449-701, Republic of Korea

\author{
Mesbah Babalar and Mojtaba Delshad \\ Department of Horticultural Sciences, College of Agricultural Science and \\ Engineering, Campus of Agriculture and Natural Resources, University of \\ Tehran, Karaj, 31587-77871, Iran
}

Sang-Gyu Lee and Yun-Chan Huh

National Horticultural Research Institute, Rural Development Administration, Suwon 440-706, Republic of Korea

Additional index words. photosynthetic characteristics, mineral composition, grafting

\begin{abstract}
Photosynthetic characteristics, concentrations of mineral elements in xylem sap, and some vegetative traits of 'Khatooni' melon were compared with those of melons grafted onto three Cucurbita rootstocks cvs., Ace, Shintozwa, and ShintoHongto, and trained with three methods: T1) no pinching and fruit thinning; T2) pinched to produce two lateral branches; and T3) pinched to two branches and all the flowers and lateral branches from lower nodes thinned. Internal $\mathrm{CO}_{2}$ and water use efficiency varied with rootstocks. Stem diameter of scions, aerial fresh and dry weights, mean fruit weight and yield, electric conductivity, $\mathrm{pH}$, and sap volume per plant of grafted plants were higher in grafted melons than in the nongrafted ones. These traits were unaffected by training methods. Mineral concentrations varied considerably depending on the rootstocks and training methods used. Xylem sap collected from the decapitated stem base of grafted melons trained with $\mathrm{T} 2$ and $\mathrm{T} 3$ methods contained a higher amount of mineral ions, especially $\mathrm{NO}_{3}^{-}, \mathrm{PO}_{4}{ }^{3-}$, and $\mathrm{K}^{+}$, than did the sap from own-rooted plants. The increase in the mineral levels in sap resulting from grafting was most apparent in 'Khatooni' grafted onto 'ShintoHongto' rootstock.
\end{abstract}

Melons (Cucumis melo L.) are one of the important fruiting vegetable crops grown in Iran and are cultivated widely in temperate and subtropical climates. Iran is the third largest melon-producing country in the world with 1.2 million t/year (FAOSTAT, 2007). Melon cultivation is performed mostly under open fields and low tunnels for early production in eastern and central regions of Iran. Under Iranian conditions, 'Khatooni' melon (Inodorus group) is the most popular commercial cultivar grown in larger areas. To

Received for publication 21 Oct. 2009. Accepted for publication 5 Mar. 2010.

This study was supported by the Research Fund of Tehran University in Iran and the National Horticultural Research Institute of RDA, Suwon, Republic of Korea.

${ }^{1}$ To whom reprint requests should be addressed; e-mailsalehir@ut.ac.ir. several European countries (Edelstein et al., 2004; Lee and Oda, 2003). Rootstocks are used in these countries to overcome soilborne diseases caused by successive cropping. In addition to disease resistance, grafted plants frequently exhibit improved yield and tolerance to low soil temperatures by increasing water and plant nutrients uptake (Ahn et al., 1999; Lee, 1994; Lee and Oda, 2003; Rivero et al., 2003; Yetisir and Sari, 2004). In some cases, the rootstock's vigorous root system increases the efficiency of water and nutrient absorption and may also serve as a source of endogenous plant hormones, thus leading to increased yield in addition to disease control (Lee, 1994). Grafting influences absorption and translocation of phosphorus, nitrogen, magnesium, iron, and calcium ions. Absorption and translocation of other micronutrients such as iron and boron are also influenced by the rootstock (Rivero et al., 2004). Concentrations of nitrogen, phosphorus, calcium, and magnesium in xylem saps increased in grafted plants (Nie and Chen, 2000). Ion influx allows increased light energy transformation efficiency, $\mathrm{CO}_{2}$ conductivity, dark reaction activity, and photosynthetic rate in the scion (Sun et al., 2002). Increased photosynthesis can often be realized under suboptimal growing conditions such as weak sunlight and low $\mathrm{CO}_{2}$ concentration in solar greenhouses during winter months, allowing grafted plants to produce higher yields and sometimes improved fruit quality. The photosynthesis rate of grafted melon plants decreases drastically during late stages of fruit development. This decrease of photosynthesis may be responsible for low fruit quality (Xu et al., 2005). However, no studies are available on the photosynthesis performance of grafted plants for Iranian melons.

Despite the importance of the grafted seedlings in vegetable cultivation, there are few studies on the influence of training methods and movement of minerals in Iranian melons. Our hypothesis is that grafting may enhance overall plant growth and produce large fruits without rigorous pruning and thinning. To verify this hypothesis, a greenhouse experiment was carried out to test this hypothesis. Grafted and ungrafted melon plants were carefully evaluated in terms of leaf gas exchange and mineral composition in xylem sap.

\section{Materials and Methods}

Plant materials and grafting. The experiments were conducted in a plastic greenhouse during 2008 at the National Horticultural Research Institute of Rural Development Administration, located in Suwon, Republic of Korea. Seeds of 'Khatooni' melon (an openpollinated cultivar) and the three Cucurbita rootstocks (Table 1) were sown simultaneously and separately in cells with $6 \mathrm{~cm}$ diameter and 4.5 deep (32-cell seedling trays) filled with a mixture (v:v) of coco peat $(65 \%$ to $70 \%)$, peatmoss $(8 \%$ to $12 \%)$, vermiculite ( $10 \%$ to $14 \%$ ), zeolite ( $3 \%$ to $5 \%$ ), and perlite ( $5 \%$ to $8 \%$ ) on 4 Feb. 2008. The seedlings were grown in an environment-controlled 
Table 1. Names and characteristics of rootstocks and scions used in experiment.

\begin{tabular}{|c|c|c|c|}
\hline Rootstock & Nature & Description & Seed production company \\
\hline Ace (R1) & Hybrid & $\begin{array}{l}\text { Interspecific hybrid (C. maxima } \times C \text {. moschata) rootstock, } \\
\text { good fusarium resistance, high soil temperature tolerance, } \\
\text { and high soil moisture tolerance }\end{array}$ & DongBu HighTek., Republic of Korea \\
\hline Shintozwa (R2) & Hybrid & $\begin{array}{l}\text { Interspecific hybrid (C. maxima } \times C \text {. moschata) rootstock } \\
\text { suitable for watermelon, cucumber, oriental melon; adapted } \\
\text { to wide range of climatic condition with vigorous root } \\
\text { system and good tolerance to fusarium disease }\end{array}$ & Nongwoo Bio, Republic of Korea \\
\hline ShintoHongto (R3) & Hybrid & $\begin{array}{l}\text { Interspecific hybrid (C. maxima } \times C \text {. moschata) rootstock with } \\
\text { vigorous root system, resistance to fusarium, and low } \\
\text { temperature; also possesses excellent vigor and high fruit } \\
\text { quality and good low-temperature tolerance }\end{array}$ & Syngenta Co., Republic of Korea \\
\hline \multicolumn{4}{|l|}{ Scion } \\
\hline Khatooni (Kh) (C) & Open-pollinated & $\begin{array}{l}\text { Cucumis melo var. inodorus, produce large fruits and very } \\
\text { susceptible to soilborne diseases and powdery mildew }\end{array}$ & Gold Seed Co., Iran \\
\hline
\end{tabular}

greenhouse with $25 / 20{ }^{\circ} \mathrm{C}$ day/night temperatures and were grafted on $11 \mathrm{Feb}$. by splice grafting (Lee and Oda, 2003) at the cotyledon stage, $7 \mathrm{~d}$ after sowing. Grafted plants were transferred to a mist chamber for postgraft care [greater than $95 \%$ relative humidity $(\mathrm{RH})$ ] for $7 \mathrm{~d}$, after which the $\mathrm{RH}$ was reduced gradually for acclimatization.

Seedlings were transplanted to a plastic greenhouse 1 month later. Soil texture was loam clay. The plants were transplanted onto raised beds spaced $2 \mathrm{~m}$ from center to center and $50 \mathrm{~cm}$ between plants and grown horizontally in the greenhouse. Three training methods were applied to the grafted and nongrafted melon seedlings after transplanting: T1) no pinching and fruit thinning; T2) pinched to produce two lateral branches and all the flowers and secondary lateral branches were preserved on two primary branches; and T3) pinched to two branches and all the flowers and lateral branches from lower nodes thinned and fruits were maintained at the sixth or seventh nodes of the two primary branches. The experimental design consisted of randomized blocks with three replicates with each subplot being $8 \mathrm{~m}^{2}$. Standard cultural practices, including drip irrigation, were used. Water was applied as required at $\approx 5$-d intervals.

Leaf gas exchange measurements. Leaf gas exchange was measured $70 \mathrm{~d}$ after transplanting between $1000 \mathrm{HR}$ and $1400 \mathrm{HR}$ using a portable photosynthesis system with a 6$\mathrm{cm}^{2}$ window-leaf chamber (LI-6400; LICOR Inc.). Measurements were taken from the third expanded leaf from the stem tip of three seedlings per treatment. Net photosynthetic rate $(A)$, stomatal conductance $\left(g_{s}\right)$ to water vapor, transpiration, and leaf internal $\mathrm{CO}_{2}$ concentrations $(\mathrm{Ci})$ were estimated by the instantaneous values of humidity and $\mathrm{CO}_{2}$ concentrations of air entering and leaving the chamber were determined by the infrared gas analyzer of the portable photosynthesis system. Values of atmospheric $\mathrm{CO}_{2}$ concentration $(\mathrm{Ca})$, air temperature $(\mathrm{Ta})$, external and internal photosynthetic photon flux densities (PPFD) were obtained by the sensors of the equipment. Intrinsic water use efficiency (WUE) was calculated by the quotient between net photosynthesis/transpiration. The mean values of vapor pressure deficit, $T a$, $P P F D$ (measured by the external sensor of the chamber), and $\mathrm{Ca}$ during the leaf gas exchange measurements were $1.43 \pm 0.15$ $\mathrm{kPa}, 26 \pm 0.2{ }^{\circ} \mathrm{C}, 460.5 \pm 37.7 \mu \mathrm{mol}$ photons/ $\mathrm{m}^{-2} \cdot \mathrm{s}^{-1}$ and $398.7 \pm 0.3 \mu \mathrm{mol} \cdot \mathrm{mol}^{-1}$ air, respectively. Also fresh and dry biomass of upper organs in the grafted and nongrafted plants were quantified.

Collection and mineral analysis of xylem sap. Xylem sap was collected $85 \mathrm{~d}$ after transplanting (50 d after pollination). Own-rooted plants were cut off at a position $25 \mathrm{~cm}$ above the ground, and grafted plants were cut off 20 $\mathrm{cm}$ above the graft. The few drops of bleeding sap from the remaining stem base were discarded and the cut surface was washed with distilled water for $10 \mathrm{~min}$. Xylem sap subsequently bled at the cut surface was collected in a flask precoated with silica and wrapped with aluminum foil. After a 24-h period of collection, the volume of xylem sap was recorded and the sap was stored at $-20{ }^{\circ} \mathrm{C}$ for analysis. Ions of $\mathrm{NO}_{3}{ }^{-}$and $\mathrm{NH}^{4+}$ were analyzed by the Kjeldahl method (Kjeltec Auto 1030 Analyzer; Foss Tecator, Hoganas, Sweden). Total calcium $\left(\mathrm{Ca}^{++}\right)$, magnesium $\left(\mathrm{Mg}^{++}\right)$, and potassium $\left(\mathrm{K}^{+}\right)$ions were analyzed by an atomic absorption spectrophotometer (AA-6800; Shimadzu Corp., Kyoto City, Japan). Total phosphorus (P) was determined by the vanadomolybdophosphoric calorimetric method at $430 \mathrm{~nm}$ (ASC-5; Shimadzu Corp.). Also, volume, electrical conductivity (EC), and $\mathrm{pH}$ of bleeding xylem sap and some vegetative growth characteristics such as stem diameter of rootstock and scion, aerial fresh weight (without fruits), and dry matter of grafted and nongrafted plants were measured. Fruits were harvested when fully mature (60 to $90 \mathrm{~d}$ after anthesis) during June and July 2008. There were five harvests at 7-d intervals. The fruits from each plot were counted and weighed.

Data were statistically analyzed using SAS 9.1 software package (SAS Institute Inc., Cary, NC) by analysis of variance and by Duncan's multiple range test to determine significant differences between means.

\section{Results}

The photosynthetic characteristics of 'Khatooni' melon are shown in Table 2. No differences were observed in net photosynthesis, evaporation, or $g_{\mathrm{S}}$ between nongrafted and plants grafted onto different rootstocks. Also, type of training did not show significant differences in all of photosynthetic characteristics (Table 2). Internal $\mathrm{CO}_{2}(\mathrm{Ci})$ and WUE were affected by rootstocks, and grafted plants onto 'Shintozwa' rootstock had higher $C i$ than nongrafted ones, whereas WUE of grafted plants was lower compared with own-rooted plants (Table 2).

Xylem sap yield was $\approx 3$-fold in 'Khatooni' melon grafted on 'Ace' rootstock (233.11 mL) compared with that of nongrafted plants $(74.78 \mathrm{~mL})$. All of the grafted plants tended to bleed greater amounts of xylem sap than nongrafted plants (Table 3 ). Significant differences were not found in the xylem sap yield between controls and grafted plants in mean values of training treatments (Table 3). The average EC value of sap from grafted plants was higher than that in sap from own-rooted plants. Also, sap EC of 'Khatooni' melon in T1 training was lower than other training methods. Sap acidity $(\mathrm{pH})$ ranged from 6.02 to 6.48 and was not influenced much by the type of rootstocks or training methods used (Table 4).

The use of grafting and training caused differences in the mineral ion composition of the scion of the cultivar Khatooni, principally with regard to the ions $\mathrm{NO}_{3}^{-}, \mathrm{NH}_{4}^{+}, \mathrm{PO}_{4}{ }^{3-}$, and $\mathrm{K}^{+}$(Table 3 ). With respect to $\mathrm{NO}_{3}^{-}$, the grafted plants on all rootstocks presented values exceeding those of the control plants (960.30 $\left.\mathrm{mg} \cdot \mathrm{L}^{-1}\right)$, whereas the concentration of $\mathrm{NO}_{3}{ }^{-}$was not significantly different in the plants grown with different training methods (Table 3). In terms of $\mathrm{NH}_{4}^{+}$, the plants grafted onto 'ShintoHongto' showed higher concentration than control $\left(265.87 \mathrm{mg} \cdot \mathrm{L}^{-1}\right.$ versus $106.67 \mathrm{mg} \cdot \mathrm{L}^{-1}$ ) and other rootstocks (Table $3)$. Significant differences were not found in the $\mathrm{NH}_{4}{ }^{+}$concentration among training treatments (Table 3 ).

In the case of $\mathrm{PO}_{4}{ }^{3-}$, the higher concentrations were observed within grafted plants (Table 3). Among the grafted plants, the highest concentration of $\mathrm{PO}_{4}{ }^{3-}$ was recorded from the graft combination $\mathrm{Kh} /$ ShintoHongto, whereas the lowest concentration was recorded by ownrooted 'Khatooni' (Table 3). Significant differences were found in the $\mathrm{PO}_{4}{ }^{3-}$ concentration among plants trained with different methods (Table 3). The highest level of $\mathrm{PO}_{4}{ }^{3-}$ was 
Table 2. Effect of different rootstocks and training methods on leaf gas exchanges in 'Khatooni' melon (70 d after transplanting).

\begin{tabular}{|c|c|c|c|c|c|}
\hline Treatment & $\begin{array}{l}\text { Net photosynthesis } \\
\left(\mu \mathrm{mol} \mathrm{CO} \mathrm{CO}_{2} / \mathrm{m}^{2} / \mathrm{s}\right)\end{array}$ & $\begin{array}{c}\text { Internal } \mathrm{CO}_{2} \\
\left(\mu \mathrm{mol} \cdot \mathrm{mol}^{-1} \text { air }\right) \\
\end{array}$ & $\begin{array}{c}\text { Transpiration } \\
\left(\mathrm{mmol} \mathrm{H}_{2} \mathrm{O} / \mathrm{m}^{2} / \mathrm{s}\right)\end{array}$ & $\begin{array}{c}G_{\mathrm{S}} \\
\left(\mathrm{mol} \mathrm{H} \mathrm{H}_{2} \mathrm{O} / \mathrm{m}^{2} / \mathrm{s}\right)\end{array}$ & $\begin{array}{c}\text { WUE }^{\mathrm{z}} \\
\left(\mu \mathrm{mol} \mathrm{CO} \mathrm{C}_{2} / \mathrm{mmol} \mathrm{H}_{2} \mathrm{O}\right) \\
\end{array}$ \\
\hline $\mathrm{Kh} /$ Ace & $16.20 \mathrm{a}^{\mathrm{y}}$ & $276.29 \mathrm{ab}$ & $3.66 \mathrm{a}$ & $0.36 \mathrm{a}$ & $4.61 \mathrm{~b}$ \\
\hline Kh/Shintozwa & $17.36 \mathrm{a}$ & $289.74 \mathrm{a}$ & $4.05 \mathrm{a}$ & $0.45 \mathrm{a}$ & $4.40 \mathrm{~b}$ \\
\hline \multirow[t]{2}{*}{ Khatooni (own-rooted) } & $16.20 \mathrm{a}$ & $252.85 \mathrm{~b}$ & $3.04 \mathrm{a}$ & $0.26 \mathrm{a}$ & $5.45 \mathrm{a}$ \\
\hline & NS & $P<0.05$ & NS & NS & $P<0.05$ \\
\hline \multicolumn{6}{|l|}{ Training method ${ }^{\mathrm{x}}$} \\
\hline \multirow[t]{2}{*}{$\mathrm{T} 3$} & $16.22 \mathrm{a}$ & $276.94 \mathrm{a}$ & $3.64 \mathrm{a}$ & $0.38 \mathrm{a}$ & $4.64 \mathrm{a}$ \\
\hline & NS & NS & NS & NS & NS \\
\hline
\end{tabular}

${ }^{\mathrm{z}}$ Water use efficiency (WUE) was calculated by dividing net photosynthesis by transpiration.

${ }^{y}$ Values within columns followed by different letters differ significantly by Duncan's multiple range test at $5 \%$.

${ }^{\mathrm{x}} \mathrm{T} 1=$ no pinching and fruit thinning; $\mathrm{T} 2=$ pinched to produce two lateral branches and all the flowers and secondary lateral branches were preserved on two primary branches; and T3 = pinched to two branches and all the flowers and lateral branches from lower nodes thinned and fruits were maintained at sixth or seventh nodes of the two primary branches, respectively.

NS $=$ nonsignificant.

Table 3. Mineral ion concentration in bleeding xylem sap of 'Khatooni' melon as influenced by rootstocks and training methods ( $85 \mathrm{~d}$ after transplanting).

\begin{tabular}{|c|c|c|c|c|c|c|c|c|c|}
\hline \multirow[b]{2}{*}{ Treatment } & \multirow{2}{*}{$\begin{array}{l}\text { Sap/plant } \\
(\mathrm{mL} / 24 \mathrm{~h})\end{array}$} & \multirow{2}{*}{$\begin{array}{c}\text { Sap/100 g FW } \\
(\mathrm{mL} / 24 \mathrm{~h})\end{array}$} & \multicolumn{6}{|c|}{ Mineral ion concn (mg 1-1 sap) } & \multirow[b]{2}{*}{ Total } \\
\hline & & & $\mathrm{NO}_{3}^{-}$ & $\mathrm{NH}_{4}^{+}$ & $\mathrm{PO}_{4}^{3-}$ & $\mathrm{K}^{+}$ & $\mathrm{Ca}^{2+}$ & $\mathrm{Mg}^{2+}$ & \\
\hline \multicolumn{10}{|l|}{$\overline{\text { Scion/rootstock }}$} \\
\hline $\mathrm{Kh} /$ Ace & $233.11 \mathrm{a}^{\mathrm{z}}$ & $7.57 \mathrm{a}$ & $1257.40 \mathrm{~b}$ & $206.73 \mathrm{~b}$ & $457.41 \mathrm{a}$ & $470.16 \mathrm{~b}$ & $176.16 \mathrm{ab}$ & $76.98 \mathrm{a}$ & $2644.8 \mathrm{~b}$ \\
\hline $\mathrm{Kh} /$ ShintoHongto & $158.56 \mathrm{ab}$ & $7.70 \mathrm{a}$ & $1676.70 \mathrm{a}$ & $265.87 \mathrm{a}$ & $469.13 \mathrm{a}$ & $649.42 \mathrm{a}$ & $131.75 \mathrm{~b}$ & $82.10 \mathrm{a}$ & 3275 a \\
\hline \multirow[t]{2}{*}{ Khatooni (own-rooted) } & $74.78 \mathrm{~b}$ & $5.42 \mathrm{c}$ & $960.30 \mathrm{c}$ & $106.67 \mathrm{c}$ & $279.45 \mathrm{~b}$ & $299.62 \mathrm{c}$ & $151.46 \mathrm{ab}$ & $74.63 \mathrm{a}$ & $1872.1 \mathrm{c}$ \\
\hline & $P<0.05$ & $P<0.05$ & $P<0.01$ & $P<0.01$ & $P<0.05$ & $P<0.01$ & $P<0.05$ & NS & $P<0.01$ \\
\hline \multicolumn{10}{|l|}{ Training method ${ }^{y}$} \\
\hline \multirow[t]{2}{*}{$\mathrm{T} 3$} & $182.83 \mathrm{a}$ & $6.674 \mathrm{a}$ & $1299.80 \mathrm{a}$ & $174.12 \mathrm{a}$ & $351.31 \mathrm{~b}$ & $493.98 \mathrm{a}$ & $159.68 \mathrm{ab}$ & $74.74 \mathrm{ab}$ & $2553.7 \mathrm{~b}$ \\
\hline & NS & NS & NS & NS & $P<0.05$ & $P<0.01$ & $P<0.01$ & $P<0.05$ & $P<0.01$ \\
\hline
\end{tabular}

${ }^{2}$ Values within columns followed by different letters differ significantly by Duncan's multiple range test at $5 \%$.

${ }^{y}$ See Table 2 for details.

$\mathrm{FW}=$ fresh weight; $\mathrm{NS}=$ nonsignificant.

Table 4. Electrical conductivity (EC) and $\mathrm{pH}$ of bleeding xylem sap and some vegetative growth characteristics of 'Khatooni' melons grafted onto different rootstocks and trained with different methods.

\begin{tabular}{|c|c|c|c|c|c|c|c|c|}
\hline \multirow[b]{2}{*}{ Treatment } & \multicolumn{6}{|c|}{$85 \mathrm{~d}$ after transplanting } & \multicolumn{2}{|c|}{ After harvesting } \\
\hline & $\begin{array}{c}\text { Sap EC } \\
\left(\mathrm{mS} \cdot \mathrm{cm}^{-1}\right)\end{array}$ & Sap pH & $\begin{array}{c}\text { Stem diam of } \\
\text { rootstock }(\mathrm{mm})\end{array}$ & $\begin{array}{l}\text { Stem diam of } \\
\text { scion }(\mathrm{mm})\end{array}$ & $\begin{array}{c}\text { Fresh wt of } \\
\text { aerial part }(\mathrm{kg})\end{array}$ & $\begin{array}{c}\text { Dry wt of } \\
\text { aerial part }(\mathrm{g})\end{array}$ & $\begin{array}{c}\text { Fresh wt of } \\
\text { aerial part }(\mathrm{kg})\end{array}$ & $\begin{array}{c}\text { Dry wt of } \\
\text { aerial part }(\mathrm{g})\end{array}$ \\
\hline \multicolumn{9}{|l|}{ Scion/rootstock } \\
\hline Kh/Shintozwa & $4.54 \mathrm{a}$ & $6.02 \mathrm{~b}$ & $14.11 \mathrm{a}$ & $14.64 \mathrm{a}$ & $2.57 \mathrm{ab}$ & $236.80 \mathrm{ab}$ & $4.5 \mathrm{a}$ & $504 \mathrm{ab}$ \\
\hline $\mathrm{Kh} /$ ShintoHongto & $4.95 \mathrm{a}$ & $6.11 \mathrm{~b}$ & $12.72 \mathrm{a}$ & $14.48 \mathrm{a}$ & $2.06 \mathrm{bc}$ & $189.86 \mathrm{bc}$ & $4.05 \mathrm{ab}$ & $454.41 \mathrm{bc}$ \\
\hline \multirow[t]{2}{*}{ Khatooni (own-rooted) } & $3.26 \mathrm{~b}$ & $6.48 \mathrm{a}$ & - & $10.11 \mathrm{~b}$ & $1.38 \mathrm{c}$ & $142.27 \mathrm{c}$ & $3.26 \mathrm{c}$ & $401.30 \mathrm{c}$ \\
\hline & $P<0.01$ & $P<0.01$ & NS & $P<0.01$ & $P<0.01$ & $P<0.05$ & $P<0.01$ & $P<0.05$ \\
\hline $\mathrm{T} 2$ & $4.81 \mathrm{a}$ & $6.08 \mathrm{a}$ & $9.63 \mathrm{a}$ & $13.63 \mathrm{a}$ & $1.99 \mathrm{a}$ & $194.62 \mathrm{a}$ & $4.07 \mathrm{a}$ & $479.44 \mathrm{a}$ \\
\hline \multirow[t]{2}{*}{$\mathrm{T} 3$} & $4.43 a$ & $6.28 \mathrm{a}$ & $10.56 \mathrm{a}$ & $13.39 \mathrm{a}$ & $2.74 \mathrm{a}$ & $247.42 \mathrm{a}$ & $4.58 \mathrm{a}$ & $504.25 \mathrm{a}$ \\
\hline & $P<0.01$ & NS & NS & NS & NS & NS & NS & NS \\
\hline
\end{tabular}

${ }^{2}$ Values within columns followed by different letters differ significantly by Duncan's multiple range test at $5 \%$ or $1 \%$.

${ }^{\mathrm{y}}$ See Table 2 for details.

NS $=$ nonsignificant.

obtained from the T2 training method. The plants trained with the T3 method showed lower $\mathrm{PO}_{4}^{3-}$ values than did other plants (Table 3 ). The results of $\mathrm{K}^{+}$(Table 3 ) revealed significant differences between grafted plants and their respective controls, whereas the highest $\mathrm{K}^{+}$concentration was obtained with the 'ShintoHongto' rootstock. The lowest $\mathrm{K}^{+}$ concentrations were found in ungrafted plants. $\mathrm{K}^{+}$levels showed significant differences in training treatments (Table 3); the highest concentration was found in $\mathrm{T} 2$ plants and the lowest levels of $\mathrm{K}^{+}$were recorded in the plants trained with the T1 method (Table 3).

The results of the $\mathrm{Ca}^{2+}$ concentration reflected significant differences between grafted plants and their respective controls (Table 3). Grafted 'Khatooni' onto 'ShintoHongto' showed the lowest $\mathrm{Ca}^{2+}$, whereas the greatest concentration was found in the combination $\mathrm{Kh} /$ Shintozwa. $\mathrm{Ca}^{2+}$ concentration in the xylem sap of the plants trained with the T1 method was lower than that from the plants trained with other methods (Table 3). No significant differences between the grafted and nongrafted plants in the $\mathrm{Mg}^{2+}$ concentration of xylem sap were found with either rootstock (Table 3). Differences in $\mathrm{Mg}^{2+}$ concentration were observed among training treatments (Table 3 ). The $\mathrm{Mg}^{2+}$ concentration was higher for T2 plants than T1 and T3.

In relation to aerial fresh weight, expressed in $\mathrm{kg} /$ plant (Table 4), significant differences were found between controls and grafted plants $85 \mathrm{~d}$ after transplanting and harvesting time. Ungrafted 'Khatooni' 
plants had the lowest aerial fresh weight at both times. 'Ace' gave the highest aerial fresh weight with scion 'Khatooni' (Table 4). Dry weight of aerial plants was significantly affected by grafting (Table 4). The highest aerial dry weight was recorded in 'Khatooni' onto 'Ace' rootstock with $271.34 \mathrm{~g}$ per plant, whereas the ungrafted plants had the lowest with $142.27 \mathrm{~g} 85 \mathrm{~d}$ after transplanting. These values increased to $554 \mathrm{~g}$ to grafted plants on 'Ace' rootstock and $401.30 \mathrm{~g}$ to ungrafted plants after final fruit harvesting time (Table 4). About fruits, the highest dry matter was obtained with ungrafted fruits (Table 5).

Significant differences were found between the diameter of scion stem in grafted and nongrafted plants (Table 4). The diameter of the scion stem was higher in grafted plants than own-rooted ones, whereas no significant differences were found in the diameter of rootstock stem among plants grafted on different rootstocks (Table 4). No significant differences between the training treatments in aerial fresh weight, aerial dry matter, diameter of rootstock, or scion of plants were found (Table 4).

Fruit yield varied among plants grafted onto the various rootstocks with different training methods. The variation was expressed mainly in the different numbers and size of fruits developed on the various rootstocks and training methods (Table 5). The use of 'Ace' and 'Shintozwa' rootstocks caused a significant increase in yield per plant of cv. Khatooni grown under greenhouse conditions. Also, the T3 training method showed the highest yield per plant (Table 5). The mean fruit weight was also significantly affected by grafting and training methods (Table 5).

In all measurements, the interactions between rootstocks and training methods were not significant.

Relative percentage of mineral ion compositions in xylem sap of grafted and nongrafted plants is shown in Figure 1. Among mineral ions, the concentration of $\mathrm{NO}_{3}{ }^{-}$was the highest in the sap of all treatments and the graft combination $\mathrm{Kh} /$ Ace trained with the T1 method (R1T1) had the highest $\mathrm{NO}_{3}{ }^{-}$ concentration $(54.53 \%)$. The lowest concentration of $\mathrm{NO}_{3}^{-}(43.38 \%)$ was found in the combination $\mathrm{Kh} /$ Ace trained with the $\mathrm{T} 3$ method (R1T3). The $\mathrm{Mg}^{2+}$ ion showed the lowest concentration in xylem sap among treatments (Fig. 1).

\section{Discussion}

In the present experiment, grafting did not affect net $\mathrm{CO}_{2}$ assimilation rate significantly $(A)$, but grafted plants had more net $\mathrm{CO}_{2}$ assimilation rate than ungrafted ones. In the hetero-grafted plants, the increase was accompanied by a significant increase in $g_{\mathrm{S}}$ and intercellular $\mathrm{CO}_{2}$ concentration $\left(C_{\mathrm{i}}\right)$, implying that high $g_{\mathrm{S}}$ was responsible for the increasing intercellular $\mathrm{CO}_{2}$ concentration and net $\mathrm{CO}_{2}$ assimilation rate by grafting. $\mathrm{He}$ et al. (2009) reported a significant reduction in the net $\mathrm{CO}_{2}$ assimilation rate in ungrafted and self-grafted plants of tomato under salinity conditions resulting from sto-

Table 5. Yield and yield components of 'Khatooni' melon as influenced by grafting and training methods.

\begin{tabular}{lccccc}
\hline Treatment & $\begin{array}{c}\text { No. of marketable } \\
\text { fruit/plant }\end{array}$ & $\begin{array}{c}\text { Mean fruit } \\
\text { wt }(\mathrm{kg})\end{array}$ & $\begin{array}{c}\text { Marketable } \\
\text { yield (t/ha) }\end{array}$ & $\begin{array}{c}\text { No. of unmarketable } \\
\text { fruits/plant }\end{array}$ & $\begin{array}{c}\text { Fruit dry } \\
\text { matter (\%) }\end{array}$ \\
\hline Scion/rootstock & & & & & \\
$\quad$ Kh/Ace & $3.66 \mathrm{a}^{\mathrm{z}}$ & $3.81 \mathrm{~b}$ & $59.7 \mathrm{a}$ & $4.66 \mathrm{~b}$ & $8.26 \mathrm{c}$ \\
Kh/Shintozwa & $3.66 \mathrm{a}$ & $3.93 \mathrm{a}$ & $61.9 \mathrm{a}$ & $5.33 \mathrm{a}$ & $9.93 \mathrm{~b}$ \\
Kh/ShintoHongto & $2.66 \mathrm{~b}$ & $3.70 \mathrm{c}$ & $39.2 \mathrm{~b}$ & $4.33 \mathrm{c}$ & $9.81 \mathrm{~b}$ \\
Khatooni (own-rooted) & $1.5 \mathrm{c}$ & $3.25 \mathrm{~d}$ & $24.3 \mathrm{c}$ & $4.00 \mathrm{~d}$ & $11.22 \mathrm{a}$ \\
& $P<0.01$ & $P<0.01$ & $P<0.01$ & $P<0.01$ & $P<0.01$ \\
Training method & & & & & \\
T1 & $2.75 \mathrm{~b}$ & $3.70 \mathrm{~b}$ & $40.8 \mathrm{~b}$ & $5.00 \mathrm{a}$ & $9.81 \mathrm{a}$ \\
T2 & $2.62 \mathrm{c}$ & $3.73 \mathrm{a}$ & $38.8 \mathrm{c}$ & $4.75 \mathrm{a}$ & $10.05 \mathrm{a}$ \\
T3 & $3.25 \mathrm{a}$ & $3.58 \mathrm{c}$ & $48.1 \mathrm{a}$ & $4.00 \mathrm{a}$ & $9.56 \mathrm{a}$ \\
& $P<0.01$ & $P<0.01$ & $P<0.01$ & NS & NS \\
\hline
\end{tabular}

${ }^{\mathrm{z}}$ Values within columns followed by different letters differ significantly by Duncan's multiple range test at $5 \%$ or $1 \%$.

${ }^{\mathrm{y}}$ See Table 2 for details.

$\mathrm{NS}=$ nonsignificant.

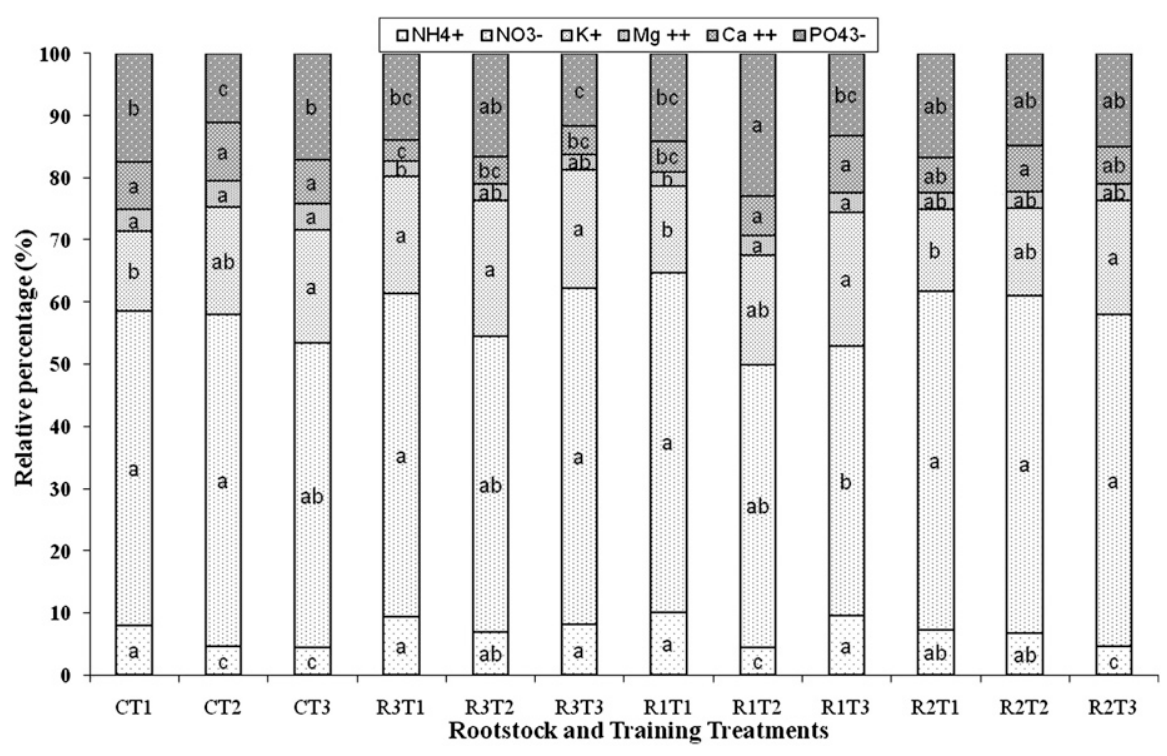

Fig. 1. Relative percentages of major mineral ion compositions in xylem sap of grafted and non-grafted 'Khatooni' melon as influenced by rootstocks and training methods. C: Control, R1: Ace rootstock, R2: Shintozwa rootstock, R3: ShintoHongto rootstock, T1: No pinching and fruit thinning, T2: Pinched to produce 2 lateral branches, and T3: Pinched to 2 branches and all the flowers and lateral branches from lower nodes thinned.

matal limitation. WUE was the highest in ungrafted melon plants (Table 2) owing to the lowest of transpiration rate and $g_{\mathrm{S}}$.

These results indicate that the pattern of mineral absorption in 'Khatooni' was markedly influenced by the type of rootstocks and training methods used. Similar results have been reported with other crops grafted onto different rootstocks (Masuda, 1989; Masuda and Gomi, 1982). In the present study, the rate of exudation from grafted plants was higher than the nongrafted ones. These results suggest that the root activity of Cucurbita rootstocks may be higher than that of 'Khatooni' melon. Salehi et al. (2009) reported that the highest root activity $\left(1.13 \mathrm{mg} \cdot \mathrm{g}^{-1} \mathrm{DW} / \mathrm{h}\right.$ formazan) was obtained in 'Khatooni' melon grafted onto 'Shintozwa' rootstock $60 \mathrm{~d}$ after grafting, whereas the lowest root activity $(0.83$ $\mathrm{mg} \cdot \mathrm{g}^{-1} \mathrm{DW} / \mathrm{hr}$ formazan) was in nongrafted ones. The concentrations of $\mathrm{NO}_{3}^{-}, \mathrm{NH}_{4}^{+}$, $\mathrm{PO}_{4}{ }^{3-}$, and $\mathrm{K}^{+}$in the exudates were higher in the grafted melons than in the nongrafted ones. The superior growth of melons onto rootstocks may depend on its superiority in nutrient and water uptake under greenhouse conditions. Masuda et al. (1986) compared mineral concentrations of xylem exudates of watermelon/squash collected at $20 \mathrm{~d}$ after pollination with those of watermelon/bottle gourd and nongrafted watermelon and found 1) high concentrations of $\mathrm{P}, \mathrm{Ca}$, and $\mathrm{Mg}$ in watermelon/squash; 2) high $\mathrm{K}$ concentration in watermelon/bottle gourd; and 3) no difference in $\mathrm{NO}_{3}-\mathrm{N}$ concentration among rootstocks. This trend of mineral composition was slightly different from our results obtained at $14 \mathrm{~d}$ after pollination. In tomatoes, Masuda and Shimada (1993) found that the yield and mineral concentration of xylem exudates had a diurnal rhythm; e.g., P concentration was higher at night than it was in the day and $\mathrm{K}$ concentration was higher in the day than at night.

In plants trained with different methods, xylem sap exudation rate was similar in all plants. Among mineral ions, only $\mathrm{NO}_{3}{ }^{-}$and $\mathrm{NH}_{4}{ }^{+}$failed to show significant differences. 
Plants trained with $\mathrm{T} 2$ and $\mathrm{T} 3$ methods showed the highest mineral composition in xylem sap. It is considered that in T2 and T3 treatments, earlier fruit set resulted to high absorption of ions such as $\mathrm{PO}_{4}{ }^{3-}, \mathrm{K}^{+}, \mathrm{Ca}^{2+}$, and $\mathrm{Mg}^{2+}$. Yamasaki et al. (1994) reported that in watermelon/bottle gourd, only $\mathrm{Ca}$ concentration at $14 \mathrm{~d}$ after pollination was decreased by the two-fruited treatment at $14 \mathrm{~d}$ after pollination, but by harvest, all mineral concentrations except $\mathrm{K}$ decreased. In contrast, in watermelon/squash, despite a slight decrease in exudate yield, there was no significant decrease in $\mathrm{Ca}, \mathrm{K}$, and $\mathrm{Mg}$, but a slight increase in $\mathrm{NO}_{3}-\mathrm{N}$ and $\mathrm{P}$ was observed in the two-fruited treatment at harvest.

The higher yield of melon from grafted plants observed in this study also had been reported earlier on tomato (Fernandez-Garcia et al., 2004), melon (Ruiz et al., 1997; Ruiz and Romero, 1999), and cucumber (Salehi et al., 2004). The lowest marketable yield recorded in self-grafted plants was associated with reduction in mean fruit weight and number of fruits per plant. These results coincided with the findings of Edelstein et al. (2004) and Traka-Mavrona et al. (2000) who found that grafting melon onto Cucurbita rootstock enhances production by increasing both fruit number and weight. It was demonstrated that grafting directly affects plant yield (Nielsen and Kappel, 1996; Rivero et al., 2003) by interactions of some or all of the following processes: increase of water and nutrient uptake as a result of the vigorous root system of the rootstock (Lee, 1994; Ruiz et al., 1997; Salehi et al., 2009) enhanced production of endogenous hormones (Zijlstra et al., 1994) and/or enhancement of scion vigor (Leoni et al., 1990). The joint interactions of some or all of these processes could explain the higher yield in melon from hetero-grafted plants observed in the current study.

\section{Conclusion}

The results of the present work indicate that most photosynthetic characteristics were not influenced by rootstocks and training methods. Compositions as well as the relative amount of most cations and anions were influenced by the rootstocks and training methods, reflecting the significant variations in their xylem sap concentrations in scion plants onto 'ShintoHongto' and 'Shintozwa' rootstocks. However, the concentrations of $\mathrm{NO}_{3}{ }^{-}$and $\mathrm{NH}_{4}{ }^{+}$in xylem sap of grafted and nongrafted plants were unaffected by the training methods. Heterografted plants showed the highest aerial fresh and dry weight, mean fruit weight, and yield.

\section{Literature Cited}

Ahn, S.J., Y.J. Im, G.C. Chung, B.H. Cho, and S.R. Suh. 1999. Physiological response of graftedcucumber leaves and rootstock roots by low root temperature. Sci. Hort. 81:397-408.

Baljee, S., L.J. Mangal, and M.L. Pandita. 1982. Effect of pruning and plant spacing on the flowering and fruit of muskmelon. Hari. Agri. Uni. Res. 12:46-68.

Buitelaor, K. 1987. Stem numbers and pruning of melons. HortScience 58:1069 (abstr.).

Duwalda, J.G. and R.E. Freeman. 1986. Melon: Effect of vine pruning and nitrogen on yields and quality. HortScience 57:2112 (abstr.).

Edelstein, M., Y. Burger, C. Horev, A. Porat, A. Meir, and R. Cohen. 2004. Assessing the effect of genetic and anatomic variation of Cucurbita rootstocks on vigour, survival and yield of grafted melons. J. Hort. Sci. Biotechnol. 79: 370-374.

FAOSTAT. 2007. 23 June 2007. <http://faostat. fao.org/site/340/default.aspx $>$.

Fernandez-Garcia, N., V. Martinez, A. Cerda, and M. Carvajal. 2004. Fruit quality of grafted tomato plants grown under saline conditions. J. Hort. Sci. Biotechnol. 79:995-1001.

He, Y., Zh. Zhu, J. Yang, X. Ni, and B. Zhu. 2009. Grafting increases the salt tolerance of tomato by improvement of photosynthesis and enhancement of antioxidant enzymes activity. Environ. Exp. Bot. 66:270-278.

Kashi, A. and B. Abedi. 1999. Effect of pruning and fruit thinning on yield and quality of melon (Cucumis melo L.) cultivars. Iranian J. Agr. Sci. 29:619-626 [in Persian].

Lee, J.M. 1994. Cultivation of grafted vegetables. I. Current status, grafting methods and benefits. HortScience 29:235-239.

Lee, J.M. and M. Oda. 2003. Grafting of herbaceous vegetable and ornamental crops. Hort. Rev. (Amer. Soc. Hort. Sci.) 28:61-124.

Leoni, S., R. Grudina, M. Cadinu, B. Madedu, and M.G. Carletti. 1990. The influence of four rootstocks on some melon hybrids and a cultivar in greenhouse. Acta Hort. 419:127-134.

Masuda, M. 1989. Mineral concentration in xylem exudates of tomato and cucumber plants at midday and midnight. J. Jpn. Soc. Hort. Sci. 58: 294-298.

Masuda, M. and K. Gomi. 1982. Diurnal changes of the exudation rate and the mineral concentration of xylem sap after decapitation of grafted and ungrafted cucumbers. J. Jpn. Soc. Hort. Sci. 51:293-298.

Masuda, M. and Y. Shimada. 1993. Diurnal changes in mineral concentrations of xylem exudates in tomato plants and their concentrations as affected by sunlight intensity and plant ages. J. Jpn. Soc. Hort. Sci. 61:839-845 [in Japanese with English summary]

Masuda, M., T. Takamori, T. Tanaka, H. Takahashi, and M. Sugio. 1986. Studies on the characteristics of nutritional uptake of the rootstocks of grafted fruit crops. VII. Fruit quality and water and mineral absorption in watermelon grafted to squash and to bottle gourd interstock, p. 180
181. Abstr. Japan. Soc. Hort. Sci. Spring Meet. [in Japanese].

Nie, L.C. and G.L. Chen. 2000. Study on growth trends and physiological characteristics of grafted watermelon seedlings. Acta Agriculturae Boreali-Occidentalis Sinica 9:100-103.

Nielsen, G. and F. Kappel. 1996. Bing sweet cherry leaf nutrition is affected by rootstocks. HortScience 31:1169-1172.

Papadopoulos, A.P. 1994. Growing greenhouse seedless cucumbers in soil and soilless media. Agriculture and Agri-Food Canada. 29-30.

Rivero, R.M., J.M. Ruiz, and L. Romero. 2003. Role of grafting in horticultural plants under stress conditions. Food. Agr. Environ. 1:7074.

Rivero, R.M., J.M. Ruiz, and L. Romero. 2004. Iron metabolism in tomato and watermelon plants: Influence of grafting. J. Plant Nutr. 27:2221-2234.

Ruiz, J.M., A. Belakbir, A. Lopez-Cantarero, and L. Romero. 1997. Leaf-macronutrient content and yield in grafted melon plants: A model to evaluate the influence of rootstock genotype. Sci. Hort. 71:227-234.

Ruiz, J.M. and L. Romero. 1999. Nitrogen efficiency and metabolism in grafted melon plants. Sci. Hort. 81:113-123.

Salehi, R., A. Kashi, S.G. Lee, Y.C. Huh, J.M. Lee, M. Babalar, and M. Delshad. 2009. Assessing the survival and growth performance of Iranian melon to grafting onto Cucurbita rootstocks. Kor. J. Hort. Sci. Technol 27:1-6.

Salehi, R., A. Kashi, and H. Lessani. 2004. The effects of different cucurbit rootstocks on growth and yield of greenhouse cucumber. Iranian J. Hort. Sci. Technol. 5:59-66 [in Persian].

Sun, Y., W. Huang, X.H. Tian, Y. Wu, C.T. Zhou, and Q. Ding. 2002. Study on growth situation, photosynthetic characteristics and nutrient absorption of grafted cucumber seedlings. Plant Nutr. Fert. Sci. 8:181-185, 209.

Traka-Mavrona, E., M. Koutsika-Sotiriou, and T. Pritsa. 2000. Response of squash (Cucurbita spp.) as rootstock for melon (Cucumis melo $\mathrm{L}$ ). Sci. Hort. 83:353-362.

Xu, C.Q., T.L. Li, and H.Y. Qi. 2005. Effects of grafting on the photosynthetic characteristics, growth situation, and yield of netted muskmelon. China Watermelon and Melon 2:1-3.

Yamasaki, A., M. Yamashita, and S. Furuya. 1994. Mineral concentrations and cytokinin activity in the xylem exudate of grafted watermelons as affected by rootstocks and crop load. J. Jpn. Soc. Hort. Sci. 62:817-826.

Yetisir, H. and N. Sari. 2004. Effect of hypocotyl morphology on survival rate and growth of watermelon seedlings grafted on rootstocks with different emergence performance at various temperatures. Turk. J. Agr. For. 28:231237.

Zijlstra, S., S.P.C. Groot, and J. Jansen. 1994. Genotypic variation of rootstocks for growth and production in cucumber; possibilities for improving the root system by plant breeding. Scientia. Hort. 56:185-186. 